\title{
PRAGMALINGVISTIČKI PRISTUP ANALIZI HUMORISTIČNOG SADRŽAJA O COVID-19 PANDEMIJI
}

\author{
Iva Borić1 , Jelena Hadžić ${ }^{2}$ \\ Grimms institut, Zagreb, Hrvatska ${ }^{1}$; Hrvatski studiji, Sveučilište u Zagrebu, Zagreb, Hrvatska E Alma Mater Europaea, \\ Maribor, Slovenija
}

\section{Sažetak}

Pojava pandemije COVID-19 rezultirala je mnogim neobičnim i neočekivanim situacijama kojima su gotovo svi stanovnici Republike Hrvatske bili izloženi na svim područjima života. Navedena promjena društvene situacije uzeta je kao primjer toga da kontekst mijenja značenje jezičnog iskaza, odnosno, osim uobičajenih značenja sadržaja, pojavljuju se i nova značenja koja prije pojave pandemije nisu postojala. Za pragmalingvističku analizu sadržaja koja je primijenjena u ovom radu, ključ je kontekst po kojem dešifriramo značenje. Svrha rada je istražiti vrste razgovornih maksima koje se krše u jezičnim iskazima humorističnog sadržaja, prikupljenog tijekom ožujka 2021. Sadržaj se sastoji od primjera prikupljenih iz vrela interpersonalne i grupne komunikacije.

Upotreba jezika kroz humor kao narativ u prvi plan stavlja i samu snagu tropa, kao što su metafora, metonimija, sinegdoha, implikatura itd. Bez njih se gubi mogućnost „širenja horizonta“, odnosno istraživanje teritorija između običnog i neobičnog. Budući da većina humora već samom formiranju krši neke od maksima, moguće interpretacije proučavanih humorističnih jezičnih iskaza, primjeri su kako kontekst i kršenje maksima, kao osnovnih pretpostavki racionalnog razgovora dovode do novog značenja i humorističnog efekta (ili dodatnog humorističnog okidača, različitog od postojećeg, u novom kontekstu).

\section{Ključne riječi}

humor, pandemija Covid 19, konverzacijske implikature, razgovorne maksime, pragmalingvistička i komunikološka analiza sadržaja

\section{Uvod}

Predmet ovog istraživanja je humoristični sadržaj koji se odnosi na pandemiju COVID-19 i koji je komuniciran u vrijeme početka pandemije na prostoru Republike Hrvatske, dakle u ožujku 2020. godine. Prvi slučaj zaraze COVID-19 priopćen je javnosti 25. veljače 2020. godine, a 19. ožujka 2020. godine na snagu stupaju mjere koje je proglasio Stožer civilne zaštite Republike Hrvatske.
Pojava pandemije COVID-19 rezultirala je mnogim neobičnim i neočekivanim situacijama kojima su gotovo svi stanovnici Republike Hrvatske bili izloženi na svim područjima života. Promjene su nastale i u jezičnom izričaju.

Navedena promjena društvene situacije uzeta je kao primjer toga da kontekst mijenja značenje jezičnog iskaza, odnosno, osim uobičajenih značenja sadržaja, pojavljuju se i nova značenja koja prije pojave (određene) društvene promjene nisu postojala.

Kao predmet istraživanja uzet je samo humoristični sadržaj razmijenjen $u$ interpersonalnoj i 
grupnoj komunikaciji, odnosno sadržaj za koji sudionici komunikacije već pretpostavljaju da je humorističan. Za pragmalingvističku analizu sadržaja koja je primijenjena u ovom radu ključ je kontekst po kojem dešifriramo značenje.

Svrha rada je istražiti konverzacijske implikature, odnosno koje se značenje, uz ono doslovno, još nalazi u humorističnom sadržaju.

Svrha komunikacije je prijenos poruke od pošiljatelja prema primatelju. Ta pretpostavka vrijedi i za komunikaciju koja se odvija kroz humor. Pretpostavka bona fide komunikacije, kako ju je definirao H.P.Grice, a objasnio Tkalac S., jedna je od pretpostavki komunikacije koja nam može služiti i za razumijevanje humora.

„...U bona fide komunikaciji podrazumijeva se da se narator trudi da iznese istinite i relevantne informacije, slušatelj je svjestan toga i primljene informacije uzima kao istinite i relevantne. Narator i slušatelj $u$ bona fide načinu prema tome na neki način surađuj. Svaki put kad se javi sumnja u istinitost ili relevantnost informacija, slušatelj smatra da je nešto krivo razumio i pokušava naći neku alternationu informaciju koja će očuvati istinitost $i$ relevantnost primljenih informacija (na taj se način $u$ bona fide komunikaciji uspješno rješavaju aluzije i implikacije)."/1/

"Naime, non-bona fide način komunikacije koristi se između ostalog kod glume, laganja i humora. Cilj ovog načina nije prijenos informacija, nego manipuliranje sa sugovornikom kako bi se postigao određeni efekt. Kako je u našoj kulturi pričanje vica društveno prihvatljivije od glume i laganja, a i češće se javlja, ono će vjerojatno biti sljedeći izbor sugovornika." /1/ Humor se sam po sebi već bazira na kršenju ili zaobilaženju „normiranih“ značenja. Način na koji je nešto smiješno je jednostavnije predstaviti nego koliko i zašto je to smiješno. Često faktor „običnosti“ u svakodnevnoj komunikaciji i spontano poštivanje pravila komunikacije uzimamo zdravo za gotovo. Osnovni set pravila, poznat pod nazivom načelo kooperativnosti, skup je jednostavnih pravila koja su prisutna u komunikaciji. Iako se "običnost" poštivanja pravila u društvu godinama podrazumijevala, filozof jezika Paul Grice je predstavio i definirao načelo kojim se govornici vode, kako bi se komunikacija odvijala bez nesporazuma, nepotrebnih zapleta ili neistinitih tvrdnji - načelo kooperativnosti. /2/
Podrazumijeva se poštivanje/praćenje određenih obrazaca, tj. ispunjavanje očekivanja. Griceov kooperativni princip /2/ prema kojem se konverzacijske implikature objašnjavaju, prikazuje kako odstupanje od maksima, odnosno njihovo kršenje, potiče izlet u nepoznato, samo odstupanje od uobičajene upotrebe, traženje primjerenog značenja, različito od onog inherentnog. Takav način komuniciranja bona fide rezultira smjernicama koje idu u prilog učinkovitoj upotrebi jezika sprečavajući prethodno spomenute poteškoće. Prema Karlić V. koja objašnjava Grievocu teoriju implikatura, konverzacijske implikature su:

1. Maksima kvalitete („Sve je u najboljem redu. " znači da ništa nije u redu) predstavlja ironični iskaz, gdje informacije iz izvanjezičnog konteksta upućuju da je sadržaj neistinit.

2. Maksima kvantitete manifestira se kroz višak ili manjak sadržaja koji sugovornik želi prenijeti npr. kroz tautologiju ,it is what it is" "što je tu je".

3. Maksima relevantnosti je prividno irelevantna replika koja služi kao upozorenje sugovorniku. Pod pretpostavkom o poštivanju principa konverzacijske suradnje, neizbježan je zaključak da u iskazu mora postojati dodatni implicitni sadržaj.

4. Maksima načina predstavlja način na koji je nešto izrečeno čime se implicira dodatni sadržaj. /3/

Pretpostavka kako implikature doprinose humoru znači da u običnim, gramatički korektnim izjavama značenje je iskazano jedno po jedno, ne prikazuje/ne izjavljuje se više stvari odjednom. Humor kroz implikature reflektira mogućnost poimanja više različitih, suprotstavljenih značenja u isto vrijeme.

Polazeći od opisa šale kao silogizma s pretpostavkom /4/; formula uključuje put $\mathrm{k}$ apsurdnom, kroz same implikature moguće je objasniti humor kao nusprodukt ili čak dodatni alat $\mathrm{u}$ razvoju jezika.

Konverzacijske implikature funkcioniraju $\mathrm{u}$ svakodnevnom govoru i značenja koja se međusobno isključuju nisu problem. Do poteškoća (ili grumena zlata u slučaju humora) u razumijevanju dolazi u trenutcima u kojima su govor- 
nici neusklađeni s obzirom na pozadinu, kontekst ili očekivanja. Slično se događa i u humoru; predznanje je ključ za dešifriranje humora i igra važnu ulogu.

U samom humoru je kontekst ključ po kojem (de)šifriramo poruku, odnosno stvaramo vezu između običnog i neobičnog, poznatog i nepoznatog.

Uloga konteksta $\mathrm{u}$ analizi diskursa, prema Song L., jest:

a) Uklanja dvosmislenost (kod riječi, fraza, rečenica ili rečeničnih skupina s više od jedne moguće interpretacije).

b) Indikacija referenata - kako bi se izbjeglo ponavljanje koristimo zamjenice, glagolske i druge fraze (vrijeme, mjesto i sl.).

c) Detektiranje konverzacijske implikature. /5/

Detektiranje konverzacijske implikature je ključno za ovaj rad.

Prema Grice, H. P. (u /5/) razlikuje se ono što govornik može implicirati, sugerirati, misliti, u odnosu na ono što je zapravo rečeno. Pravo se značenje reducira na temelju razgovornog značenja riječi s kontekstom na temelju kooperativnog principa i 4 maksime - kvalitete, kvantitete, relevantnosti i načina. Grice $H$. P. je sustavno proučavao slučajeve u kojima se ono što govornik MISLI razlikuje od onoga što njegova izjava neposredno ZNAČI. /5/

$\mathrm{U}$ svemu navedenom radi se o kodiranim podatcima koji su u načelu dio enciklopedijskog znanja, no ovisno o kontekstu dolazi do pomaka/asocijacija.

Dakle, novo značenje je proizašlo kao posljedica novog konteksta

Koja su obilježja konverzacijskih implikatura (prema Blome-Tillmann, M.)?

1.) Moguće ih je poništiti. Same implikature su dio onog što je komunicirano, a ne izrečeno i samim time govornik ima mogućnost poreći da su jezičnim iskazom imali namjeru komunicirati određeni sadržaj. U nekim se slučajevima (osim kod eksplicitnog humora koji je jasan zbog publike, konteksta i sadržaja) to može smatrati i izlazom u slučaju nužde u škakljivim situacijama.

2.) Neodvojive su (izuzev maksime načina).
Implikature nisu dio jezične forme, već su povezane sa semantičkim sadržajem onoga što je rečeno, njihova „snaga“ se ne umanjuje niti ne nestaje promjenom izraza, odnosno korištenjem sinonima.

3.) Moguće ih je izračunati (objasniti).

Za svaku navodnu implikaturu moguće je konstruirati argument koji pokazuje kako od doslovnog značenja ili smisla iskaza s jedne strane i načela kooperativnosti i maksima s druge strane, zaključujemo da primatelj rekonstruira taj put kako bi se očuvalo načelo kooperativnosti.

4.) Nekonvencionalne su.

Konverzacijske implikature nisu dio konvencionalnog značenja jezičnog izraza.

Budući da je potrebno znati doslovno značenje rečenice prije no što je moguće izračunati implikaturu u njenom kontekstu, one ne mogu biti dio značenja. /6/

Nakon što su opisani mogući načini kršenja maksima, potrebno je spomenutu kategorizaciju primijeniti na primjere.

Humor je prisutan $\mathrm{u}$ interpersonalnoj i grupnoj komunikaciji i zasigurno doprinosi značenju odaslane poruke. Uz pojam "korona“ ili bez njega, igre riječima, referencama i tragovima pop kulture prikazane kroz jezična sredstva kršenja načela bona fide komunikacije i dalje (p)ostaju idealan primjer osnovnih načela komunikacije. Osim komunikacijske funkcije jezika, humor je i podsjetnik kako nam uvijek ostaje i razonoda, razvoj i kreativnost.

Upotreba jezika kroz humor kao narativ u prvi plan stavlja i samu snagu tropa, kao što su metafora, metonimija, sinegdoha, implikatura itd. Bez njih se gubi mogućnost „širenja horizonta“, odnosno istraživanje teritorija između običnog i neobičnog.

$S$ obzirom na to da nam jezik rješava nedoumice, za razlike $\mathrm{u}$ komunikacijskim previranjima kontekst je ključan u određivanju ispravnog tumačenja. Novo značenje ostvaruje se $u$ kontekstu pandemije COVID-19 i svih promjena svakodnevice koje su nastupile pojavom pandemije.

Neki oblici humorističnog sadržaja postojali su $\mathrm{u}$ sličnom obliku i prije pojave pandemije $\mathrm{CO}$ VID-19, ali im je kontekst odredio novo, odnosno dodatno značenje. 


\section{Ciljevi istraživanja}

Cilj ovog istraživanja je ustanoviti odnos promijenjenog konteksta uzrokovanih pojavom pandemije COVID-19 i humorističnih sadržaja i to kroz konverzacijske implikature.

Specifični ciljevi su:

- istražiti koje se maksime kooperativnosti krše

- istražiti na koji se način krše maksime kooperativnosti

- istražiti vezu između humora i implikatura

- detektirati nova značenja, povezana s kontekstom pandemije COVID-19, koja humoristični sadržaj nosi.

\section{Metodologija}

Metoda ovog istraživanja je kvalitativna analiza sadržaja iz pragmalingvističke perspektive.

Jedinica analize je humoristični sadržaj komuniciran $\mathrm{u}$ (privatnoj) interpersonalnoj ali i grupnoj komunikaciji, poslan putem digitalnih komunikacijskih kanala. Humorističan sadržaj može biti u formi jezičnih iskaza, slike ili video uratka. Analizom su obuhvaćeni tekstualni, slikovni, zvučni i video djelovi humorističnog sadržaja. Jedinicom analize obuhvaćeni su i eventualni tekstualni dodatci koje je pošiljatelj dodao poslanom sadržaju, ponekad stvarajući humor kroz kombinaciju poslane slike i popratnog teksta.

Svi analizirani humoristični sadržaji odnose se na ožujak 2020. godine. Na ovaj način su obuhvaćeni oni sadržaji koji su se pojavili na samom početku pandemije u Hrvatskoj.

U uzorku su se nalazile 202 humoristične objave poslane ili primljene tijekom ožujka 2020. koje su bile povezane s pandemijom COVID-19 ili situacijama koje su povezane s pojavom pandemije.

Jedinice sadržaja slijede ciljeve istraživanja i glase:

1. Krši li se maksima kvalitete?

2. (ako se krši maksima kvalitete) Na koji se način krši maksima kvalitete?

3. Krši li se maksima kvantitete?
4. (ako se krši maksima kvantitete) $\mathrm{Na}$ koji se način krši maksima kvantitete?

5. Krši li se maksima relevantnosti?

6. (ako se krši maksima relevantnosti) $\mathrm{Na}$ koji se način maksima relevantnosti?

7. Krši li se maksima načina?

8. (ako se krši maksima načina) Na koji se način krši maksima načina?

9. Koja se nova značenja, povezana s pandemijom COVID-19 mogu iščitati iz sadržaja?

10. Kako implikature mogu utjecati na samo značenje, odnosno kako se finalno značenje mijenja dodatnim impliciranjem uz kontekst?

\section{Rezultati}

U rezultatima su predstavljeni primjeri - humoristični jezični iskazi - i njihovo tumačenje kroz pragmalingvistički pristup analizi sadržaja. Budući da većina humora već samom formiranju krši neke od maksima, moguće interpretacije proučavanih humorističnih jezičnih iskaza primjeri su kako kontekst i kršenje maksima kao osnovnih pretpostavki racionalnog razgovora dovode do novog značenja i humorističnog efekta (ili dodatnog humorističnog okidača, različitog od postojećeg, u novom kontekstu).

Kroz primjere iz uzorka, u većini se slučajeva sadržaj mogao opisati kroz kršenje maksime kvalitete ili načina. Imajući na umu da se humor, kao što je spomenuto ranije, postiže obratima, „stvaratelj” humorističnog sadržaja namjerno krši maksimu kvalitete, odnosno namjernom upotrebom dvoznačnosti krši se maksima načina.

Druga opcija u kojoj primalac poruke svjesno krivo tumači sadržaj zapravo ima jednaku težinu jer se i na taj način krše temelji komunikacijskih maksima.

Važno je spomenuti kako kršenja maksime kvalitete nije samo binarna pojava u kojoj se humor postiže govorenjem ili prokazivanjem neistine, već gledano kroz kontekst, na sličan se način hiperkorektnost i doslovno shvaćanje mogu dodati na popis okidača humora. 
95

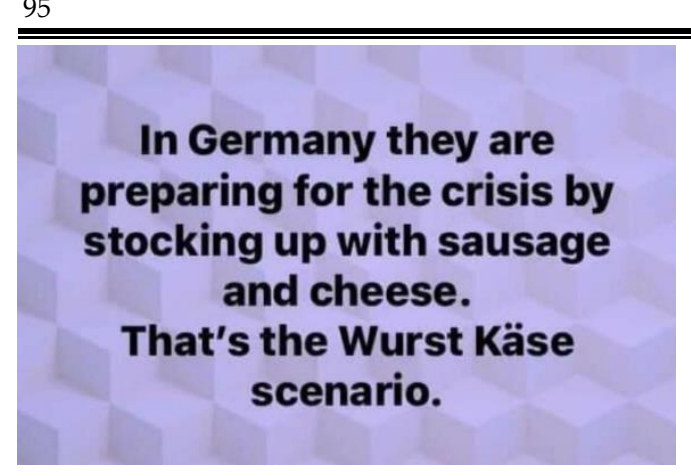

Primjer 1
Homonimija - ljepota je u jednostavnosti. Riječi koje jednako/slično zvuče ostvaruju komični moment. U ovom slučaju se radi o primjeru koji bi i izdvojen iz konteksta krize idealno funkcionirao, no pandemija i gomilanje zaliha dodatno obogaćuje slojeve smiješnoga. Ovo je primjer kršenja maksime načina. Oblik fraze „Wurst Kase“ u doslovnom se značenju odnosi na kobasice i sir, kao poznatih delicija karakterističnih za njemačko i austrijsko govorno područje, no spominjanjem krize, čak i bez eksplicitnog navođenja da se radi o pandemiji COVID-19, fraza "Wurst Kase“ ne znači samo kobasice i sir, već implicira i da se radi o engleskoj frazi koja slično zvuči „,worst case scenario“ (najgori mogući scenarij).

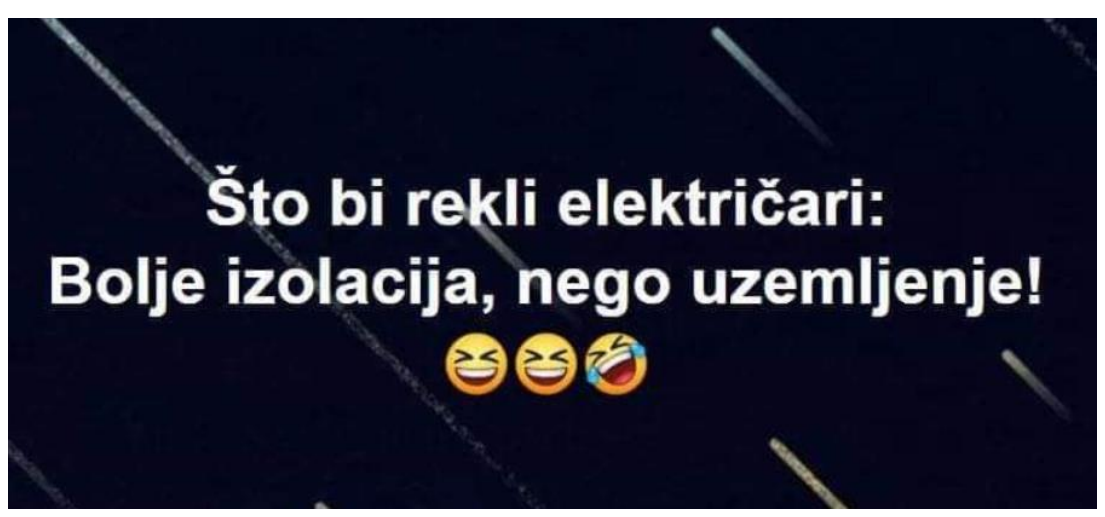

U nastavku vidimo još jedan primjer kršenja maksime načina kroz dvosmislenost. U kontekstu električara, izolacija i uzemljenje označavaju potpuno različite postupke $\mathrm{i}$ također mogu biti smiješni, dok u kontekstu pandemije izolacija kao jedna od preporučenih mjera štiti od nas "uzemljenja" odnosno groba.

Primjer 2

wittyidiot

@stephenszczerba

Me Drinking Home Alone 2019:

Sad

Disturbing

Loser

Me Drinking Home Alone 2020:

Citizen

Inspiration

Hero

Primjer 3
Uobičajena situacija u kojoj netko doma sam pije je do prije godinu dana bila negativno obojena, dok je za vrijeme pandemije preporučeno ostati doma i promjenom situacije/konteksta mijenja se značenje. Implicira se na „herojski“ čin ostanka doma i spašavanja života kroz izbjegavanje širenja zaraze, što je u potpunoj suprotnosti s uobičajenim implikaturama čina „pijem alkoholna pića sam doma“ (tzv. "solo-drinker“6). Samim time krši se maksima načina.

\footnotetext{
${ }^{6}$ „Solo-drinker“ je pejorativni izraz za osobu koja prekomjerno uživa u alkoholnim pićima, bez društvenog povoda. Često se „solo-drinkera“ opisuje kao osobu na granici s alkoholizmom.
} 


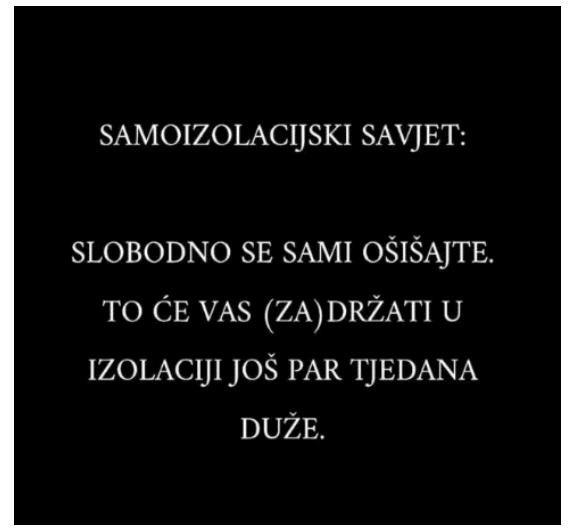

U primjeru 4 prikazuje se kršenje maksime kvalitete tako da dobronamjerni savjet "Slobodno se sami ošišajte." u ovom slučaju nije benevolentan jer se podrazumijeva da smo svi nevješti u šišanju samih sebe (naravno, izuzev samih frizera). Činom šišanja samog sebe implicira se negativan rezultat, koji bi osobu koja se pokušala ošišati sama odvratio od izlaska iz kuće zbog srama spram svoga izgleda, čime slijedimo pandemijska pravila ponašanja.

Primjer 4

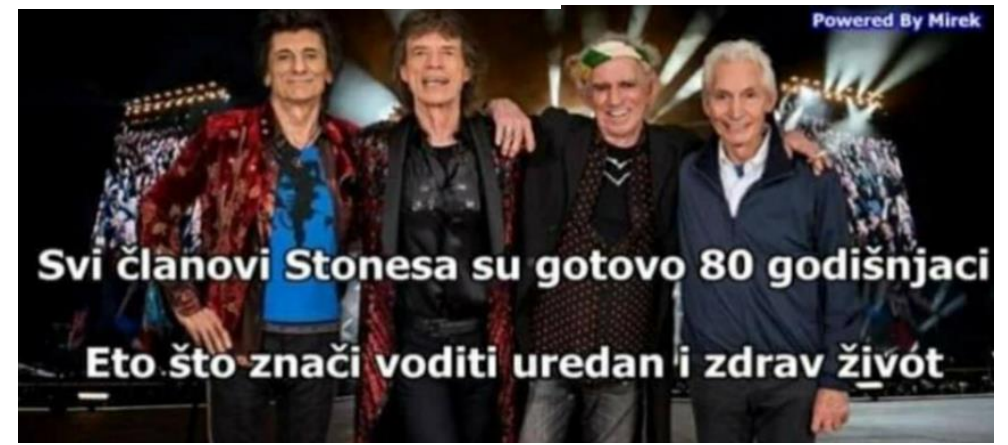

Primjer 5

Primjer 5 odnosi se na kršenje maksime kvalitete. Uobičajeno značenje fraze "voditi uredan i zdrav život" u kontekstu koji se odnosi na osobe starije životne dobi podrazumijeva uzročno-posljedičnu vezu između zdravog života i dugovječnosti. U ovom primjeru tvrdnja koja je prividno istinita zbog samog konteksta (osobe na slici, poznati rokeri jesu starije životne dobi) krši uvjet istinitosti jer je poznato da su "rock zvijezde" (pogotovo Rolling Stonesi sa slike) sklone porocima i nikako nisu primjer zdravog života par excellence. Zapravo se ovim humorističnim obratom implicira da ne postoji veza između zdravog života i dugovječnosti.

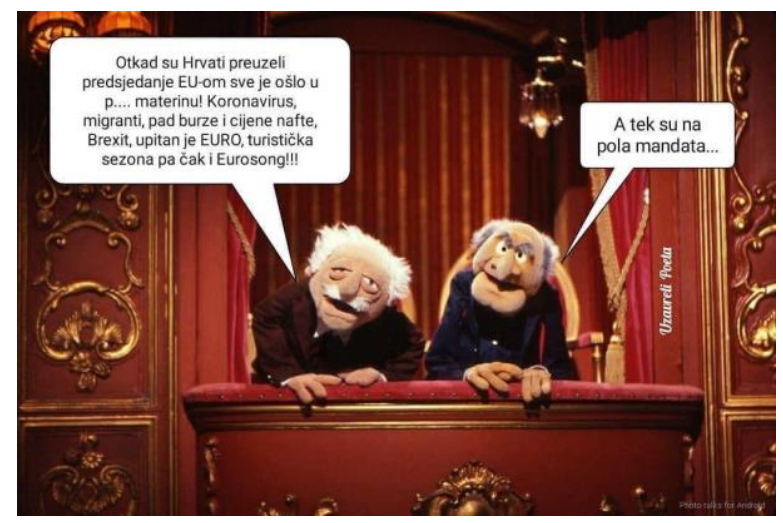

Na primjeru 6 krši se maksima načina. Implicira se da predsjedanje Hrvatske Europskom Unijom sa sobom nosi nesreću, odnosno da je predsjedanje uzrok pandemiji, padu burze i ostalim navedenim problemima.

Primjer 6 
97

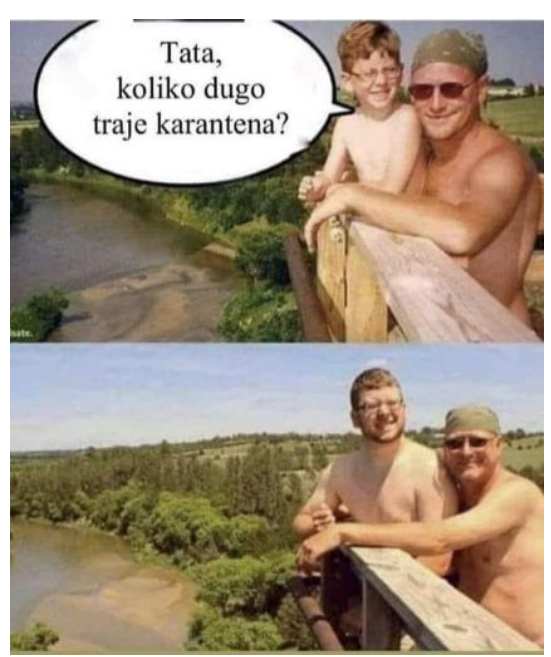

U primjeru 7 je prikazano kršenje maksime kvantitete. Slika prikazuje sina i oca u razmaku od nekoliko godina. Nedostaje eksplicitan odgovor na pitanje "Koliko dugo traje karantena?". Implicira se da je moguće da karantena potraje više godina, dovoljno da dječak s prve slike izraste u mladića s druge slike.

Primjer 7

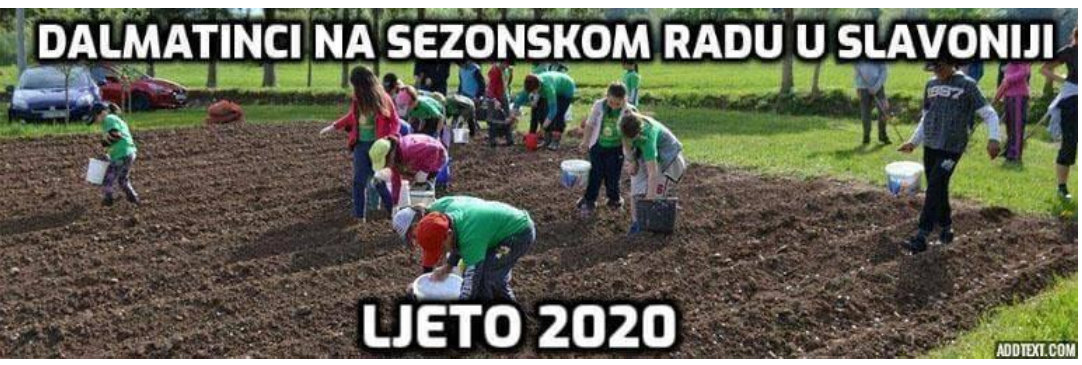

Primjer 8
U primjeru 8 prikazano je kršenje maksime kvalitete. Tvrdnja nije istinita, nego je pretjerana kroz prizmu promjene uobičajenih obrazaca migracije radne snage tijekom turističke sezone. Implicira se obrnuti scenarij, u kojem je „sezonski rad" (odnosno turistička sezona) promijenio lokaciju pa zbog zatvaranja turističkih objekata Dalmatinci idu preko sezone raditi u Slavoniju.

Adam Bedford @adambedders

Our 5 year old seems to have deemed himself the local virus warden.

Over the fence to our neighbour:

'JEAN YOU NEED TO GO INSIDE'

'Okay I will in a minute'

'YOU'RE OLD AND THERE'S A

VIRUS'

'I'm not that old thank you'

'HOW OLD ARE YOU JEAN?'

'I'm 68.'

'THAT IS NEARLY 70 JEAN.'
U primjeru 9 krši se maksima načina. Implicirano je kako su uloge između starijih osoba i djece zamijenjene. Starije osobe, koje su smatrane autoritetom djeci, sada postaju netko kome je potreban nadzor, stoga djeca u skladu s naputcima i preporukama Stožera pronalaze svrhu u brizi za starije.

Primjer 9 


\section{Joža Manolić zabrinut zbog corone, unuci su mu u rizičnoj skupini.}

\section{Primjer 10}

Ljudi, NE NASJEDAJTE i NE VJERUJTE baš svemu što nam Vlada govori! Kažu da je dovoljno u nabavku hrane ići samo s maskom i gumenim rukavicama.

Sinoć sam tako išao u šoping i ljudi oko mene su nainormalniie nosili maiice. hlače. iakne...

\section{Primjer 11}

Kršenje maksime načina $\mathrm{u}$ primjeru 10 se manifestira kroz implikaturu o starosti unuka. Spomen unuka evocira znanje o mlađoj dobi, no u slučaju političara Josipa Manolića, poznatog po navršenom 100. rođendanu, implicira se i starost njegovih unuka.

U primjeru 11 krši se maksima kvantitete, jer je zbog humorističnog efekta naputak Vlade shvaćen doslovno, odnosno „manjak informacija“ o odjeći implicira „nošenje samo maski i gumenih rukavica“.

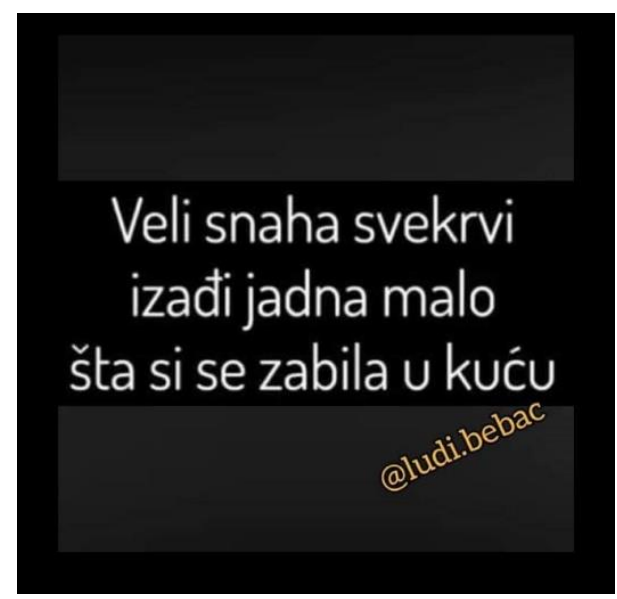

Primjer 12 prikazuje kršenje maksime relevantnosti, obzirom da se snaha svekrvi obraća kroz dobronamjeran savjet da izađe malo na zrak, no u kontekstu pandemije COVID-19 to implicira izloženost virusu. Stereotipna netrpeljivost na relaciji snaha-svekrva je dobila dodatno značenje za vrijeme spomenute krize.

Primjer 12

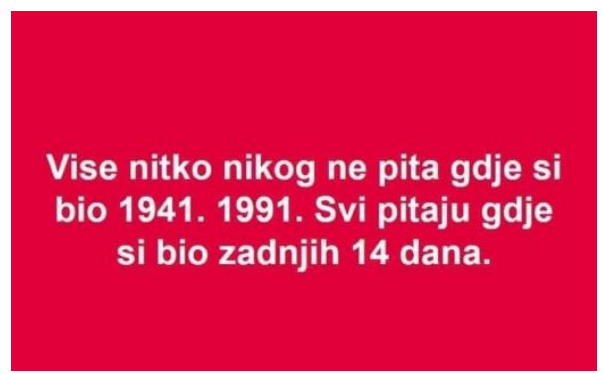

Kršenje maksima kvantitete i relevantnosti u kontekstu pandemije COVID-19 na primjeru 13 iz prvog plana miče stereotipna pitanja, proizašla iz godina koje se koriste kao argumenti u raspravama s politički obojenom pozadinom7, odnosno 1941. i 1991. kao godine koje su obilježile tok povijesti!

Primjer 13

\footnotetext{
7 Pitanjem „gdje si bio 1941. ili 1991.“ se implicira pripadnost nekoj od strana u II. svjetskom odnosno Domovinskom ratu
} 


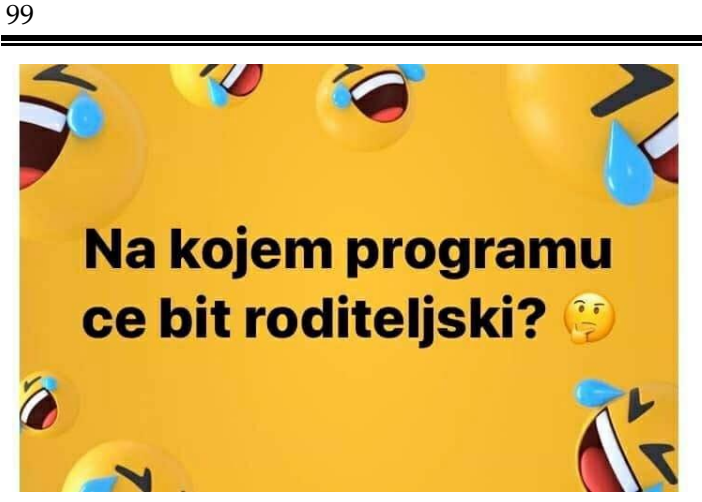

Primjer 14

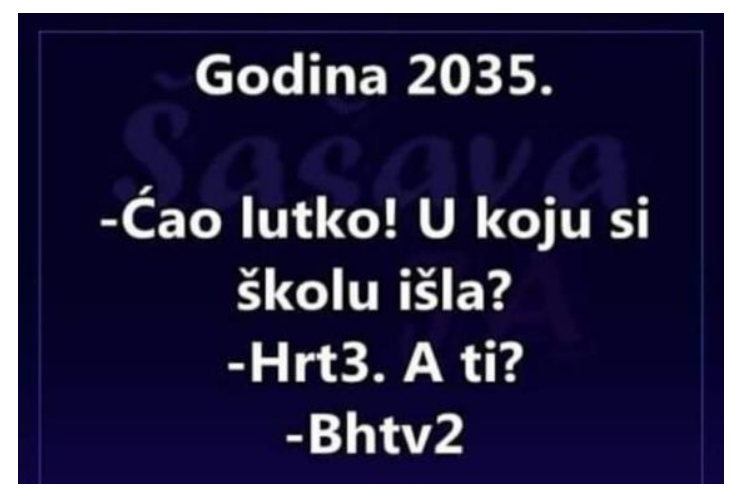

Primjer 15

\section{BITKA KOD KONZUMA (2020. god poslje Krista)}

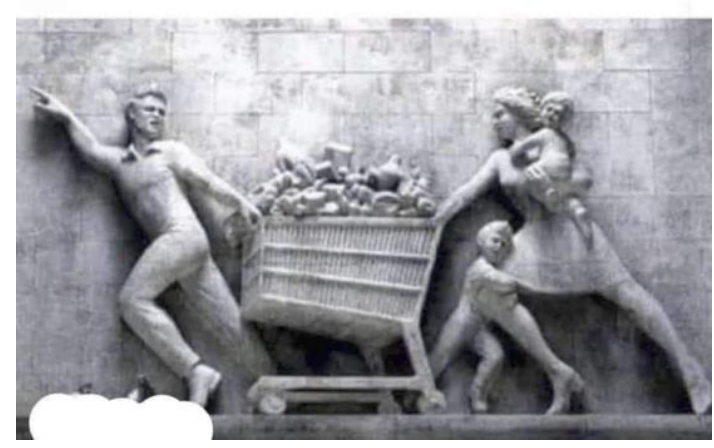

Primjer 16
Primjer 14 pokazuje kršenje maksime kvantitete. Kontekst pandemije COVID-19 je, kao što je i spomenuto u premisi ovog rada, potaknuo nova značenja. Prije same krize jezični iskaz „Na kojem programu će biti roditeljski?“ imala bi potpuno drugačije značenje - opet, ovisno o kontekstu. U ovom slučaju implicira kako će i roditelji roditeljske sastanke imati preko televizije, kao što i njihova djeca prate nastavu putem televizijskih kanala.

Primjer 15 je primjer kršenja maksime kvantitete i načina u jednom, što nije rijetkost. Kvantitativno gledano informacije su nedostatne za konstruktivan odgovor, no kontekst krize kao ključ dešifriranja objašnjava značenje iskaza kroz kratice televizijskih kanala.

Primjer 16 predstavlja kršenje maksime kvantitete. Izostavljanjem informacija o tome kakva se to točno „bitka“ odvija kod Konzuma, primatelj poruke može biti zapravo potpuno zbunjen, no u kontekstu pandemije COVID-19, čak i bez reljefa prikazanog na slici, značenje koje se dodjeljuje ovom jezičnom izrazu je da se zahvaljujući nestašici namirnica u krizi obična kupovina potrepština pretvara u gotovo gladijatorski pothvat. 


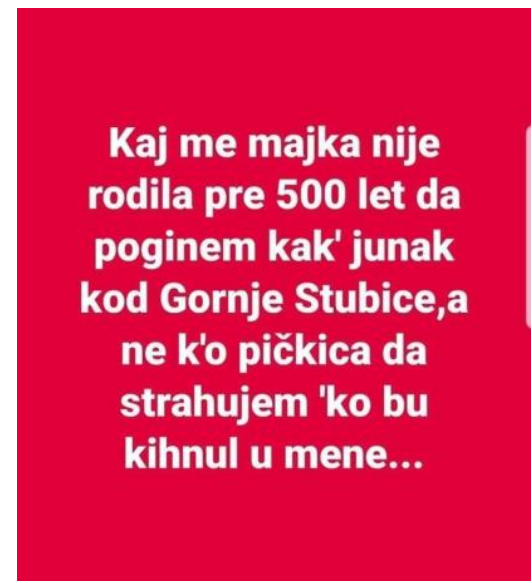

Primjer 17
Zanimljiv je primjer kršenja maksime relevantnosti u primjeru 17. Junačka pogibija podrazumijeva borbu za više vrijednosti, borbu iz strasti, smrt pod zastavom, kroz borbu za ideale, često kao simbol otpora. U kontekstu pandemije COVID-19 naizgled benigno kihanje implicira "gotovo sigurnu smrt", masovni strah od zaraze učinio je svoje.

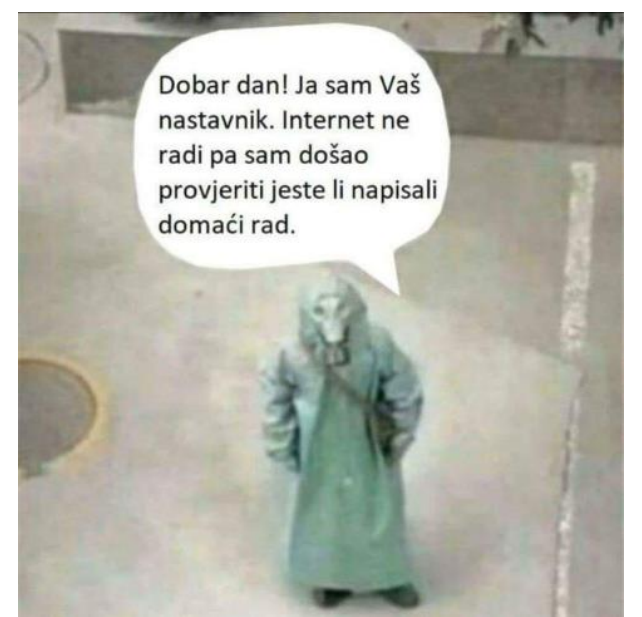

Primjer 18
Kršenje maksime relevantnosti. Izvan konteksta pandemije jezični iskaz „,Dobar dan! Ja sam Vaš nastavnik. Internet ne radi pa sam došao provjeriti jeste li napisali domaći rad." značio bi kako je nastavnik izuzetno brižan i provjerava stanje interneta svojih učenika. Sam ustroj školskog sustava je pod utjecajem krize uzrokovane pandemijom COVID-19 izmijenjen i u tom kontekstu jezični iskaz iz primjera 18 zapravo dobija značenje kako uslijed „školovanja na daljinu“ odnosno putem interneta, nastavnik nema druge opcije osim fizički ići od kuće do kuće svojih učenika, potpuno zakrabuljen u masku i odijelo zbog straha od zaraze.

\section{NAMERNO STE PUSTILI SNEG. DA VIDITE PO TRAGOVIMA, KO JE IZLAZIO IZ KUĆE.}

Primjer 19

Primjer 19 predstavlja kršenje maksime kvantitete. Bez konteksta pandemije COVID-19, s kojom ruku pod ruku idu i odluke Civilnog stožera, ovaj jezični iskaz ima neodređeno značenje, no usprkos nenavedenim informacijama „Tko je pustio?" i "zašto bi uopće bilo bitno je li netko izlazio iz kuće“ u kontekstu krize „oni koji puštaju snijeg“ su zapravo isti oni koji donose odredbe o ponašanju tijekom krize. Dodatni kontekst je i kalendarski jer je snijeg u ožujku, iako ponekad meteorološki očekivan, zapravo bio samo sol na ranu postojećih iznimnih situacija. Tragovi, odnosno stope u snijegu ispred pragova, simboliziraju "neposluh“, nepoštivanje mjera i napuštanje doma u situaciji u kojoj nam je to „preporučeno“ i čak do neke mjere zabranjeno. 


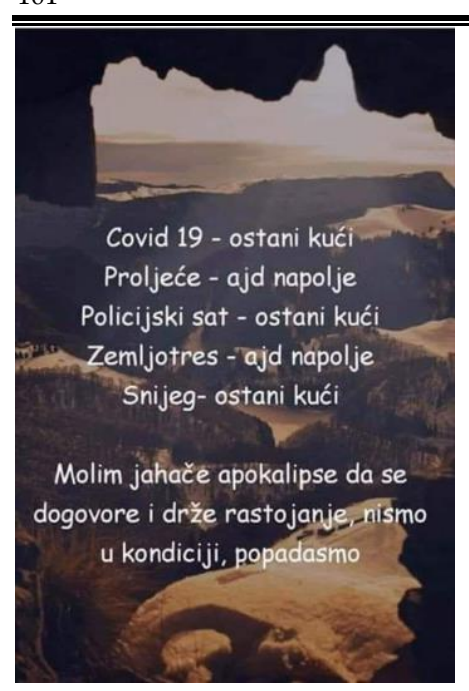

Primjer 20

Primjer 20 predstavlja kršenje maksime načina. Dok bi u doba koje je prethodilo tzv. „novom normalnom“ spregu pandemijskih mjera i prirodnih katastrofa kojima smo bili izloženi opravdano nazvali apsurdnom, u ožujku 2020. godine na zagrebačkom području mogao se osjetiti snažan potres (najsnažniji je bio jačine 5,5 stupnjeva po Richteru, u nedjelju, 22. ožujka 2020. u 6 sati i 24 minute, dok se do 14. travnja 2020. moglo osjetiti još 145 potresa magnitude iznad 1,3 stupnja po Richterovoj ljestvici. Seizmografi su zabilježili još oko 850 potresa magnituda manjih od 1,3 stupnja). Razvidno je zašto bi nakon takve prirodne katastrofe, što je bio posve neočekivan događaj u životima građana Zagreba, ovakav primjer ostavio iznimno sarkastičan i gorkohumoran dojam.

\section{Zaključak}

U analiziranom humorističnom sadržaju pronađeno je kršenje svih četiriju maksima kooperativnosti (maksima kvalitete, maksima kvantitete, maksima načina i maksima relevantnosti). Upravo zahvaljujući spomenutim kršenjima $u$ promatranom uzorku predstavljen je odnos između onoga što je izravno izrečeno i onoga što je implicirano.

Načini kršenja maksima koji su detektirani kroz ovo istraživanje očituju se kroz upotrebu informacija iz izvanjezičnog konteksta, tako upućujući na to da je sadržaj neistinit. Osim toga, upotreba polisemije, homonimije i ironije kao dobro poznatih alata u humoru, moment humorističnog obrata stavlja upravo na samo kršenje navedenih maksima.

Maksima kvalitete krši se neistinitim tvrdnjama koje dobivaju novo značenje u kontekstu, maksima kvantitete izostavljanjem informacija ili pretjeranim predstavljanjem nepotrebnih informacija, maksima načina namjernim korištenjem višeznačnosti ili općenitih izraza koji mogu biti protumačeni na različite načine, dok je maksima relevantnosti najmanje zastupljena, a u slučajevima u kojima je nalazimo krši se korištenjem jezičnih izraza koji naizgled nemaju veze s prenošenjem poruke, no kontekst im daje novo značenje.

Primjeri kršenja maksima relevantnosti možda nisu bili zastupljeni u tolikoj mjeri kao ostali unutar 202 proučavana primjera, no jedno od mogućih objašnjenja leži u pretpostavci da je sama relevantnost za humor irelevantna. Apsurd je samo produžena ruka humora (i obratno). Upravo zbog toga relevantnost je jedna od maksima za koju je pronađeno najmanje primjera. Iz toga proizlazi da jezični iskaz humorističnog sadržaja koji uključuje apsurd a priori krši maksimu relevantnosti.

Primjer spoja implikature i humora konverzacijskoj suradnji daje novu razinu. Detektiranjem konverzacijskih implikatura, zahvaljujući poznavanju razgovornog značenja riječi, na površinu dolazi i sadržaj sugeriran samim kontekstom.

Kao što je vidljivo iz rezultata istraživanja, dodavanjem samo jednog krovnog pojma sadržaju pojavljuje se dodatno novo značenje. Ta nova značenja uvelike su vezana uz preporučeno ponašanje u novonastalom kontekstu pandemije i odnose se na brigu o zdravlju, ostanak u kući, izbjegavanje socijalnih kontakata i pridržavanje fizičke distance (iako je službeni termin „socijalna distanca“, primjerenije je koristiti izraz fizička distanca, jer se distanca odnosi na preporučenu fizičku udaljenost, a ne na ukidanje ili zabranu socijalnih kontakata koji ne moraju nužno biti i fizički).

Nova značenja proizašla iz analiziranih primjera odnose se i na promjene u navikama, kao i na promjene $u$ naučenom ponašanju. Kontekst pandemije do ekstrema dovodi uobičajene radnje poput: 
1. Gledanja televizijskog programa koji postaje medij putem kojega se školarci obrazuju, umjesto u školskim klupama; umjesto uobičajene percepcije televizije kao sredstva informiranja i razonode (kao što je navedeno u primjeru 15.)

2. Pridržavanje pravila ostanka u kući i pritom sva inače društveno neprihvatljiva ponašanja dobar su razlog ako pojedinca zadrže u kući, poput loše frizure ili alkoholiziranja.

3. Nova značenja ne dobivaju samo neke pojave ili ponašanja (značenja), već i pojedine riječi same po sebi. Tako, na primjer, značenje riječi "kupovina“ sada može implicirati bitku, dok "kašljanje“ ili „kihanje“ poprimaju odlike bioterorističkog čina.

Prilikom pregleda implikatura koje su proizašle kao rezultat ovoga istraživanja, čini se izvjesnim kako sve te implikature možemo svrstati u nekoliko zajedničkih skupina. Te proizvoljne skupine, koje nisu bile primarni istraživački cilj, su dob kao predmet generacijske razlike, obitelj i stereotipne uloge koje se pripisuju članovima obitelji, normirane vrijednosti koje se $\mathrm{u}$ danim primjerima uglavnom očituju kroz kršenje maksime relevantnosti ili načina i u njima se humor manifestira kao apsurd primjena dobrih pravila za neku profesiju ili običaje. Uz to kao dvije srodne kategorije stoje i kategorija autoriteta gdje se suočavaju nadređeni i podređeni, te kategorija antagonizama gdje se humor temelji na arhetipski suprotstavljenim pojmovima. $S$ obzirom na to da ekstrakcija sadržajnih kategorija kao temelja humorističnosti nije bila sadržana u ciljevima ovog istraživanja, ovo istraživačko pitanje može biti tema nekog daljnjeg istraživanja.

Promjene okolnosti uslijed pojave COVID-19 pandemije, a koje su evidentne iz implikatura humorističnog sadržaja, odnose se na stubokom prodrmanu svakodnevicu. One su se dogodile na razini obavljanja svakodnevnih i rutinskih zadataka, izvršavanja jednostavnih zadaća poput kupovine, odlaska u školu ili na posao, druženja s prijateljima. Istodobno, naglasak na pojačanu, čak i pretjeranu, brigu za zdravlje rezultirao je pretjeranim pranjem ruku, stalnim dezinficiranjem, izbjegavanjem dodira ili blizine druge osobe te strahom od bilo kakve prisutnosti ne-zdrave osobe, što je sve vidljivo $u$ humorističnom sadržaju. U humoristični sadržaj prodrlo je i nepovjerenje prema autoritetu (u ovom slučaju se kao autoritet podrazumijeva Stožer civilne zaštite koji je donosio pravila i određivao ispravno epidemiološko ponašanje). Zanimljivo je primijetiti kako je spektar promjena svakodnevice raznolik. Iako je tema ovog istraživanja ograničena samo na COVID-19 pandemiju i posljedice te pandemije, očigledno je kako su promjene svakodnevice koje su pronašle svoje mjesto $u$ humoru puno šireg spektra od samog pitanja bolesti COVID-19 i zaraze. $\mathrm{Ne}$ bi bilo ispravno pretpostaviti da su sve društvene promjene koje su se dogodile zbog početka pandemije COVID-19 pronašle svoj put $u$ humoristični sadržaj, niti je uzorak ovog istraživanja reprezentativan, no ova jezična analiza sama po sebi ukazuje na načine prilagodbe jezika novim situacijama.

Zaključno, iako činjenica kako su ljudi prilagodili svoje ponašanje novonastaloj situacije možda nije potpuno istinito opisana kroz humor, kroz same implikacije tog humora ipak se može iščitati kako su pojedinci doživjeli promjene, dok prenaglašenost tog doživljaja daje naslutiti kako su se ljudi osjećali. Implikature humorističnog sadržaja i kršenje maksima kooperativnosti mogu poslužiti kao dobar vodič za razumijevanje stanja pojedinaca $\mathrm{u}$ ekstremnoj situaciji pojave pandemije COVID-19.

Nije nimalo jednostavan zadatak biti ,jedan od onih" koji šale raščlanjuju i svojim deskriptivnim pristupom humoru umanjuju čaroliju. $S$ druge strane, prepoznajući obrasce, moguće ih je opisati i analizirati, a samim time reproducirati, reciklirati, obogatiti i ulaštiti. Kroz ovaj rad su pragmalingvistički prikazani i opisani obrasci humorističnog sadržaja, dok je pitanje reprodukcije ostavljeno za neke daljnje analize i istraživanja.

Bilješke

/1/ Tkalac, S.; Humor: Teorije humora i Paulosov model; Hrvatsko komunikološko društvo i Nonacom, Zagreb, 2008. 
/2/ Grice, HP.; Logic and conversation, ( u Syntax and Semantics, eds: Cole, P and Jl. Morgan, Vol.3 Speech Acts), Academic Press., New York), 1975.

/3/ Karlić, V. (2015). Konverzacijska implikatura u SMS diskursu. Rasprave: Časopis Instituta za hrvatski jezik i jezikoslovlje, 41 (1), 49-63.

/4/ Raskin. V. Sematic Mechanisms of Humor D. Reidel Publishing Company, Dordrecht/Boston/ Lancaster, 1985.

/5/ Song, L.; The Role of Context in Discourse Analysis; Journal of Language Teaching and Research; vol1, No. 6., str 876-879; Academy Publisher, Manufactured in Finland; November 2010.

/6/ Blome-Tillmann, M.; (2013). Conversational Implicatures (and How to Spot Them). Philosophy Compass. 8. 10.1111/phc3.12003.

\section{Literatura}

1. Blome-Tillmann, M.; (2013). Conversational Implicatures (and How to Spot Them). Philosophy Compass. 8. 10.1111/phc3.12003.

2. Bruner, J.; Acts of Meaning; Harvard University Press, 2002.

3. Grice, HP.; Logic and conversation, ( u Syntax and Semantics, eds: Cole, P and Jl. Morgan, Vol.3 Speech Acts), Academic Press., New York), 1975.

4. Karlić, V. Konverzacijska implikatura u SMS diskursu. Rasprave: Časopis Instituta za hrvatski jezik i jezikoslovlje, 41 (1), 49-63. 2015.
5. Kalapoš, S.; The culture of laughter, the culture of tears: September 11th events echoed in the Internet, Narodna umjetnost, 39 (1), 97-113., 2002.

6. Raffaelli, I.; O značenju: Uvod u semantiku; Matica hrvatska, Zagreb, 2015.

7. Raskin. V. Sematic Mechanisms of Humor D. Reidel Publishing Company, Dordrecht/Boston/ Lancaster, 1985.

8. Raskin V., Ruch W. The Primer of Humor Research, Mouton De Gruyter, Berlin, 2008.

9. Song, L.; The Role of Context in Discourse Analysis; Journal of Language Teaching and Research; vol1, No. 6., str 876-879; Academy Publisher, Manufactured in Finland; November 2010.

10. Tkalac, S.; Humor: Teorije humora i Paulosov model; Hrvatsko komunikološko društvo i Nonacom, Zagreb, 2008.

Web lokacije

Pristupljeno 6.3.2021., Civilna zaštita Republike Hrvatske, https://civilna-zastita.gov.hr/odluke-stozeracivilne-zastite-rh-za-sprecavanje-sirenja-zaraze-koronavirusom $/ 2304$

Pristupljeno 6.3.2021., Hrvatski zavod za javno zdravstvo, https://www.hzjz.hr/priopcenja-mediji/covid-19-priopcenje-prvog-slucaja/

Pristupljeno 6.3.2021., Wikipedija https://hr.wikipedia.org/wiki/Potres_u_Zagrebu_2020.

\title{
PRAGMA-LINGUISTIC APPROACH TO THE ANALYSIS OF HU- MORIC CONTENT ABOUT THE COVID-19 PANDEMIC
}

\author{
Iva Borić1, Jelena Hadžić \\ Grimms Institute, Zagreb, Croatia ${ }^{1}$; Faculty of Croatian Studies, University of Zagreb, Zagreb, Croatia \& Alma Mater Eu- \\ ropaea, Maribor, Slovenia ${ }^{2}$
}

\begin{abstract}
The emergence of the COVID-19 pandemic has resulted in many unusual and unexpected situations in all areas of life, including language, to which almost every Croatian citizen has been exposed. This social paradigm shift exemplifies the fact that context changes the meaning of a language utterance. In other words, ordinary semantics aside, new semantic meanings have come up which haven't existed before the COVID-19 pandemic occurred.

The context by which we decipher the meaning is the key for the pragma-linguistic content analysis explored in this paper. Its purpose is to research the types of conversational maxims which are broken in humoristic utterances. The content consists of examples collected in March 2021 from a pool of interpersonal and group communication sources. Using humor in language as a narrative shines a light on tropes such as metaphor, metonymy, synecdoche, implication etc. Without them, we would lose a chance to broaden our horizons, i.e. to explore
\end{abstract}


the area between the ordinary and the extraordinary. Seeing as most humor innately breaks some maxims, the possible interpretations of the analysed utterances illustrate how context and maxim-breaking as basic principles of rational talk bring about new meanings and comic effect (or an additional comical trigger, different from the existing one, in a new context).

Key words

humour, pandemics, conversational implicatures, conversational maxim, content analysis from pragma-linguistic and communicology perspective 